\title{
A review of creatine supplementation in age-related diseases: more than a supplement for athletes [version 1; peer review: 2
} approved]

\author{
Rachel N. Smith ${ }^{1}$, Amruta S. Agharkar' ${ }^{1}$, Eric B. Gonzales ${ }^{1-3}$ \\ ${ }^{1}$ Department of Pharmacology \& Neuroscience, UNT Health Science Center, Fort Worth, TX, TX, 76107, USA \\ 2Institute for Aging and Alzheimer's Disease Research, UNT Health Science Center, Fort Worth, TX, TX, 76107, USA \\ ${ }^{3}$ Cardiovascular Research Institute, UNT Health Science Center, Fort Worth, TX, TX, 76107, USA
}

V1 First published: 15 Sep 2014, 3:222

https://doi.org/10.12688/f1000research.5218.1

Latest published: 15 Sep 2014, 3:222

https://doi.org/10.12688/f1000research.5218.1

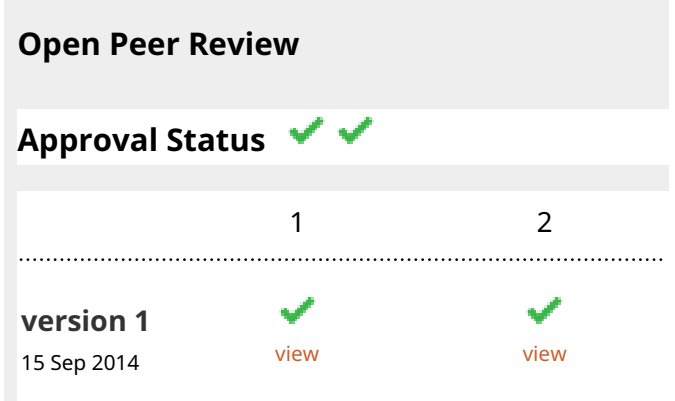

1. James Simpkins, West Virginia University Health Science Center, Baltimore, USA

2. Paula Bickford, University of South Florida College of Medicine, Tampa, USA

Any reports and responses or comments on the article can be found at the end of the article. 
Corresponding author: Eric B. Gonzales (eric.b.gonzales@unthsc.edu)

Competing interests: No competing interests were disclosed.

Grant information: Rachel N. Smith is supported by a fellowship on an NIH National Institute on Aging Training Grant (T32AG020494). Eric B. Gonzales is supported by an American Heart Association Beginning Grant-in-Aid (12BGIA8820001) and an UNTHSC Institute for Aging and Alzheimer's Disease Research (IAADR) Pilot Seed Grant.

The funders had no role in study design, data collection and analysis, decision to publish, or preparation of the manuscript.

Copyright: ( $) 2014$ Smith RN et al. This is an open access article distributed under the terms of the Creative Commons Attribution License, which permits unrestricted use, distribution, and reproduction in any medium, provided the original work is properly cited. Data associated with the article are available under the terms of the Creative Commons Zero "No rights reserved" data waiver (CC0 1.0 Public domain dedication).

How to cite this article: Smith RN, Agharkar AS and Gonzales EB. A review of creatine supplementation in age-related diseases: more than a supplement for athletes [version 1; peer review: 2 approved] F1000Research 2014, 3:222

https://doi.org/10.12688/f1000research.5218.1

First published: 15 Sep 2014, 3:222 https://doi.org/10.12688/f1000research.5218.1 


\section{Introduction}

The usage of dietary supplementation in the United States is a multibillion-dollar industry, where creatine ( $N$-[aminoiminomethyl]- $N$ methyl glycine) accounts for over 4 million $\mathrm{kg}$ and $\$ 200$ million annually ${ }^{1,2}$. Creatine is an endogenous molecule found in all cells in the body and is synthesized in the kidney, liver, and pancreas using the amino acids arginine, glycine and methionine before entering the bloodstream ${ }^{3-5}$. From the plasma, creatine is transported into the cells via the creatine transporter protein $(\mathrm{CRT})^{6,7}$. This transporter is critical for the distribution of creatine throughout the cells as well as for traversing the blood brain barrier (BBB), giving creatine access to the central nervous system (CNS).

Nearly $95 \%$ of creatine stores reside in skeletal muscle with the remaining $5 \%$ found in the brain, liver, testes, and kidneys ${ }^{8}$. Perhaps the most well understood role of creatine in physiology is its participation in energy production. More specifically, creatine maintains the intracellular levels of adenosine triphosphate (ATP) in skeletal muscle. This source of ATP is produced via oxidative phosphorylation, which is regulated by the mitochondria ${ }^{9}$. Within just a few seconds, muscle contraction utilizes the entire ATP store (2-5 mM) found in skeletal muscle ${ }^{10}$. ATP is regenerated using the phosphocreatine system where phosphocreatine donates its phosphate group to adenosine diphosphate (ADP) to form ATP. This reaction occurs rapidly and reversibly via the enzyme creatine kinase (CK), making the ATP replenishing capacity of both phosphocreatine and creatine kinase high. Conversely, at rest, ATP donates a phosphate group to creatine in order to replenish phosphocreatine stores for future muscle contraction use.

Although primarily associated with energy production, mitochondria play an important role in the production of reactive oxygen species, dysregulation of calcium, excitotoxicity, and premature cellular death ${ }^{1-14}$. Likewise, creatine has important implications in antioxidant mechanisms, controlling intracellular calcium concentrations, regulating extracellular glutamate concentrations, and preventing the opening of the mitochondrial permeability transition pore (MPT) ${ }^{15-20}$. With evidence for creatine's critical role in cellular bioenergetics, the phosphocreatine system in energy buffering, and the aforementioned implications in mechanisms associated with mitochondrial dysregulation, it is no surprising that creatine is the subject of investigation for improving the status of patients with neurodegenerative diseases that either result or progress by some mechanism of energy insufficiency.

\section{Physiological creatine concentrations and creatine supplementation}

There is a maximum capacity for the synthesis of endogenous creatine. To increase these levels, patients and athletes turn to creatine supplementation. These individuals that take in foods rich in creatine tend to have higher creatine levels ${ }^{21,22}$. The transport of creatine into cells is limited, since the capacity of creatine transport within each muscle cell is only $160 \mathrm{mmol} / \mathrm{kg}^{23}$. The possible beneficial effects of creatine are negligible if the creatine transporter is not functioning or if the maximal concentration of creatine within the cell has been reached. Evidence suggests that additives with creatine supplementation like proteins, carbohydrates, alpha lipoic acid, and D-pinitol can stimulate the movement of creatine into the cell, making creatine an ideal supplement for athletes with increased protein and carbohydrate intake ${ }^{24-27}$.

In general, a $70 \mathrm{~kg}$ human has a total creatine pool of 120 grams with 2 grams per day production from both dietary and endogenous sources $^{8,28}$. Like many other supplements, supplementation reduces the normal physiological creatine production. This reduction is reversible as creatine supplementation is terminated ${ }^{8}$. Athletes use creatine supplementation to increase creatine phosphate stores. Elevated phosphocreatine leads to the phosphorylation of ADP to ATP and aids in limiting energy depletion during rapid muscle movement. Multiple studies have indicated significant improvements in sprint performance, body mass, fat-free body mass, weightlifting volumes, oxygen uptake and overall exercise performance following creatine supplementation ${ }^{29-40}$. Creatine loading in athletes can require 20 grams per day of supplementation, while maintenance dosing is roughly 5 grams per day. These studies dosed the subjects in a similar fashion. Serum creatine levels reached $2.17 \mathrm{mM}$ and $0.8 \mathrm{mM}$ at 2.5 hours following a 20 gram and 5 gram creatine bolus, respectively ${ }^{41,42}$. Creatine is excreted in the urine as creatinine with a daily turnover of 2 grams per day. Although creatine supplementation results in reduced, but reversible natural creatine production, creatine supplementation appears to have few unwanted side effects ${ }^{43}$. Thus, creatine is an attractive dietary supplement for athletes.

Prior to the usage of creatine as an athletic enhancer, creatine has been the focus of research to understand the dietary supplement's role in physiology for 150 years. Creatine supplementation became popular during the Barcelona Olympic Games as it was shown to enhance athletic performance ${ }^{44}$. Around the same time, two studies showed that creatine enhanced exercise performance via oral creatine ingestion ${ }^{23,45}$. With a clear understanding of the creatine/ phosphocreatine system and its relation to the ADP/ATP energy metabolism in the mitochondria, studies began to shift their focus to understanding creatine's role in pathophysiological conditions.

In addition to athletic performance, creatine usage has expanded to treat pathophysiological conditions including gyrate atrophy, poststroke depression, congestive heart failure, chronic musculoskeletal pain disorders, atherosclerotic diseases and cisplatin nephrotoxicity ${ }^{28,46,47}$. Furthermore, a recent review proposed prophylactic creatine supplementation could reduce chances of preterm labor or hypoxic-ischemic encephalopathy ${ }^{48}$. Extensive research has demonstrated that the availability of phosphocreatine plays a role in skeletal muscle pathology and the associated pain can be alleviated by the intake of exogenous creatine ${ }^{49}$. New studies indicate that creatine plays a role in age-related neurological diseases and reduced brain functionality associated with Parkinson's disease, Huntington's disease, amyotrophic lateral sclerosis (ALS), long-term memory deficits, Alzheimer's disease, and stroke. In the subsequent text, we will discuss creatine's role in these neurodegenerative conditions.

Benefits of creatine supplementation in age - associated declines in the brain

General benefits

Aging is associated with lower levels of creatine and phosphocreatine, specifically in the skeletal muscle. Phosphocreatine regeneration 
rates following exercise fall approximately $8 \%$ each decade after age $30^{50}$. Creatine supplementation increases both creatine and phosphocreatine from $10-40 \%$ in athletes ${ }^{50}$. Furthermore, a recent review described a meta-analysis of the role creatine supplementation and resistance training plays on muscle health in an aging population. Based on the analysis of 13 published, creatine had an overall beneficial effect on aged individuals muscle mass ${ }^{51}$. Since the creatine transporter can readily transport creatine from the bloodstream across the $\mathrm{BBB}$, it is reasonable to suggest that exogenous supplementation of creatine would increase concentrations in the brain, where endogenous creatine levels may be diminished as a person ages. In neurodegenerative disorders (as outlined below), creatine may help slow the progression of each condition.

\section{Parkinson's disease}

Parkinson's disease (PD) is a neurodegenerative disorder resulting from the loss of dopamine neurons in the midbrain with symptoms becoming apparent when approximately $60 \%$ of these neurons are $\operatorname{lost}^{52}$. Notable symptoms of PD include resting tremor, postural instability, bradykinesia, loss of muscle mass, strength, and increased ability to fatigue. The treatment measures for PD involve early detection of the disease and understanding how to slow PD progression once symptoms have been reported. Rodent models often used for the study of PD are induced by toxins, such as 1-methyl-4-phenyl-1,2,3,6-tetrahydropyridine (MPTP), to mimic the pathogenesis and progression of the disease marked by dopaminergic neuron loss, mitochondrial dysfunction, and oxidative stress $^{53,54}$. In particular, complex I of the electron transport chain within the mitochondria is deficient in patients with Parkinson's disease. The fact that postural instability, loss of muscle mass, and strength all occur in the progression of PD, and are coupled with creatine's ability to alter cellular energetics, has led to the hypothesis that the creatine dietary supplementation could minimize the associated symptoms with Parkinson's disease.

An early study testing the benefit of creatine in MPTP-induced Parkinson's disease mice showed significant neuroprotection with $1 \%$ creatine supplementation in $\operatorname{diet}^{55}$. In 2006, a group of investigators at the National Institute of Neurological Disorders and Stroke (NINDS) began a phase III clinical trial for creatine in 200 patients affected by Parkinson's disease after second phase preliminary data showed that creatine was able to slow down the progression of the disease $^{56}$. A year later, a double-blind study compared the control group (no creatine supplementation) to the test group (20 Parkinson's disease patients), which received a creatine loading dose of 20 grams per day for 5 days and a creatine maintenance dose of 5 grams per day thereafter ${ }^{57}$. The purpose of this study was to specifically explore if creatine could help increase muscle strength in idiopathic Parkinson's disease patients. Both groups received resistance training during the study. A difference was observed in the creatine supplemented group with some of the strength exercises used versus the control group ${ }^{57}$. In September 2013, the NINDS announced that the phase III clinical trial for creatine use in Parkinson's disease was halted because the study would result in an observable significant difference ${ }^{58}$. The test subjects tolerance for creatine or creatine associated side effects were not the cause for stopping the trial. The patients in this creatine clinical trial received 10 grams creatine daily for up to 5 years. Although this outcome is disappointing, the ability for creatine to alter energy dysfunction in addition to muscle strength may still have a combinatory effect with other Parkinson's disease drug treatments. The possibility remains that creatine may be beneficial for Parkinson's disease patients, but more work needs to be done to demonstrate the dietary supplements efficacy.

\section{Huntington's disease}

Huntington's disease (HD) is a neurodegenerative disease where the onset of symptoms occurs in midlife. Once the symptoms begin, a patient can expect to live, on average, 20 more years ${ }^{59}$. Those that develop Huntington's disease possess genetically inherited mutations in the number of cytosine-adenine-guanine (CAG) repeats in the huntingtin gene responsible for producing the huntingtin protein $^{60-63}$. The huntingtin protein is expressed throughout the central and peripheral nervous systems. Upon the onset of HD symptoms, the patient begins to exhibit changes in mood, cognition, and motor coordination $^{60-63}$. In addition to contributing to an abnormal gait, resting tremor and even epileptic seizures associated with Huntington's disease, the mutant huntingtin protein product leads to impaired energy metabolism ${ }^{64}$. Without a cure for Huntington's disease, the impairment of energy metabolism offers an avenue and target for new therapies. Furthermore, there is an observed reduction in the phosphocreatine and inorganic phosphate ratio in Huntington's disease patients' muscle tissue, which may indicate the Huntington mutation's involvement in dysregulating the phosphocreatine/creatine ratio ${ }^{65}$. In a mitochondrial toxin Huntington's disease mutant mouse model, R6/2, creatine is hypothesized to act as a means of buffering, or providing a larger phosphocreatine pool for rapid conversion of ADP to ATP, energy within the cell ${ }^{5,66-68}$. Furthermore, as an extension of the work done by Matthews and colleagues $^{68}$, the Ferrante group ${ }^{69}$ showed that lifespan was extended by $9.4,17.7$ and $4.4 \%$ when supplemented with 1,2 , or $3 \%$ creatine in the diet, respectively ${ }^{69}$.

Several Huntington's disease transgenic mice strains have been developed to study the dysfunction in energy metabolism, the electron transport enzymes in the mitochondria, and excessive excitotoxicity associated with the disease ${ }^{53,70-74}$. Supplementation with exogenous creatine in one transgenic mouse model showed improved motor performance, reduced atrophy of neurons, and huntingtin protein aggregates, and an observed increased survival rate or life-span ${ }^{17,69,75}$. Following these studies, a phase II clinical trial ensued to assess creatine tolerability given at a dosage of 8 grams per day to Huntington's disease patients ${ }^{76}$. From these studies, Hersch and colleagues determined that 8-hydroxy-2'-deoxyguanosine (8OH2'dG), a marker for damaged DNA, was abnormally high in patients with $\mathrm{HD}$, but was reduced after creatine treatment ${ }^{76}$. In an interview regarding the phase III clinical trial of creatine usage in Huntington's disease patients, the CREST-E (Creatine Safety, Tolerability, and Efficacy) clinical trial, Hersch reported that $8 \mathrm{OH} 2$ 'dG had returned to normal levels. Subsequently, there was an observed reduction in brain deterioration rate when patients were supplemented with creatine and that creatine kinase is a potential biomarker for $\mathrm{HD}^{77}$. The potential of creatine as a viable therapy for HD remains to be seen and the results from CREST-E clinical trial will provide some indication to the dietary supplement's utility. Thus, creatine supplementation remains a potential therapy for Huntington's disease, however further studies are needed. 


\section{Amyotrophic lateral sclerosis}

Amyotrophic lateral sclerosis (ALS), or Lou Gehrig's disease, is marked by the loss of voluntary muscle control from the progressive degeneration of motor neurons ${ }^{78,79}$ with subsequent neuronal loss resulting in paralysis ${ }^{80,81}$. The cause and cure for ALS remain elusive. The most promising treatment is the drug riluzole, which only increases the lifespan of those with the disease by 6 months ${ }^{82}$. To complicate the search for effective treatments, as many as $50 \%$ of ALS patients experience cognitive impairment that is revealed when they undergo specialized testing for neuropsychological deficits $^{83}$. In addition to motor neuron loss observed in ALS patients, cognitive impairment most often associated with the frontotemporal region of the brain is not always present ${ }^{83}$. Furthermore, despite identifying a genetic overlap in ALS and other neurodegenerative disease mechanisms, the sporadic occurrence of cognitive impairment in ALS patients obscures understanding a clear etiology of the disease ${ }^{83}$.

At a molecular level, ALS is characterized by altered glutamate homeostasis, oxidative damage, elevated intracellular calcium concentrations, mitochondrial swelling, and electron transport chain complex I deficiencies leading to reduced energy intake ${ }^{84-87}$. Generally, mutations in the gene responsible for the production of the enzyme, superoxide dismutase (SOD1) are common in many cases of familial $\mathrm{ALS}^{80}$. The loss of function associated with SOD1 mutations reported in ALS translates to the accumulation of toxic free radicals from superoxide generated by the mitochondria ${ }^{80,88,89}$. This suggests that the build up of free radicals results in altered energy production. Thus, creatine may serve as an energy alternative that is beneficial for ALS patients.

Klivenyi and colleagues studied transgenic mice with a mutated human SOD1 gene and assessed the neuroprotective effects of creatine. This was in response to the promotion of survival and improved motor coordination they observed with long-term creatine supplementation ${ }^{90}$. Along with the proposed creatine benefits in protecting neurons from insufficient energy production, the results indicated that creatine administration protected neurons from oxidative damage. In contrast, two completed clinical trials in 2003 and 2004 tested oral creatine supplementation and provided little notable improvements in lifespan, muscle strength, or motor unit numbers in patients with ALS $^{91,92}$. Although there is an observed trend toward enhanced survival following creatine supplementation, these studies distinguished between large differences (30-50\% difference). Due to the high threshold for observing significant differences, there remains a possiblilty that creatine has a subtle effect. Currently, the long-term effects of creatine supplementation are being studied in a phase II clinical trial associated with the Northeast Amyotrophic Lateral Sclerosis Consortium (NEALS).

\section{Long-term memory}

The ability to encode new memories (working memory), recall previous events (episodic/long-term/declarative memory) and short-term (primary/active) memory declines with age ${ }^{93,94}$. Previous reports indicated that phosphocreatine stores are quickly depleted upon brain activation, while ATP concentrations remain constant $t^{95,96}$. A reduction in creatine levels may have an effect on the immediate recall of knowledge based on the dramatic drop in phosphocreatine levels from brain activation. In 2003, Rae and colleagues questioned if creatine supplementation enhanced intelligence in healthy subjects ${ }^{97}$. For 6 weeks, subjects were given 5 grams of creatine orally per day. Following this protocol, the subjects showed improvements in working memory and intelligence utilizing the backward digit span and Raven's Advanced Progressive Matrices tasks, respectively. Furthermore, each of the participants were vegetarians, which supported the role that exogenous creatine has on increasing participants' serum creatine levels. Using magnetic resonance spectroscopy to measure creatine levels, it was determined that creatine levels increased in the brain, solidifying that creatine is not solely distributed in skeletal muscle ${ }^{98}$. Creatine supplementation has been considered for the improvement of memory in the elderly. One such study in the United Kingdom reported that subjects with an average age of 76 saw improvements in long-term memory when supplemented with 20 grams per day of creatine for 1 week $^{99}$. In addition to improvement in the long-term memory task, the elderly subjects improved in both forward and backward spatial recall as well as forward number recall. Based on these results, the investigators concluded that creatine could enhance cognition in elderly subjects, although follow up studies have not elucidated a mechanism by which creatine does this. Currently, there are few studies focused on the role that creatine supplementation plays on cognition and memory. In addition, how creatine improves memory in the aforementioned studies is yet to be understood at the molecular and cellular levels.

\section{Alzheimer's disease}

Alzheimer's disease (AD) is a neurodegenerative disease marked by neurofibrillary plaques and tangles in the brain. One of the challenging characteristics of $\mathrm{AD}$ is the inability to definitively determine if a patient has the disease while alive. Only during the postmortem exam the disease can be definitively diagnosed ${ }^{100}$. However, these hallmarks can be observed in the postmortem brains of individuals that did not display dementia or deteriorated cognitive function. As the disease progresses, the symptoms include severe dementia, confusion, and the loss of long-term memory. Although the onset of $\mathrm{AD}$ is not entirely understood, studies have shown that high-energy metabolism precedes the onset of $\mathrm{AD}$ while there are increased levels of myo-inositol, an important structural component of lipids, in comparison to the relative creatine concentrations. Furthermore, this increase in the ratio of myo-inositol and creatine precedes the onset of dementia in individuals with Down's syndrome ${ }^{101-103}$. Creatine was shown to be protective of rat hippocampal neurons when confronted with beta-amyloid (A $\beta$ ) toxicity ${ }^{104}$. One possible mechanism to intervene with the progression of Alzheimer's disease is creatine kinase. Creatine kinase is responsible for the conversion of ATP to ADP and vice versa ${ }^{105}$ and tends to be susceptible to high levels of oxidative damage in the brains of Alzheimer's disease patients ${ }^{105}$. In Alzheimer's disease, creatine kinase activity is reduced by as much as $86 \%$ along with a reduction of in creatine kinase protein expression of $14 \%$, which suggests that the Alzheimer's disease brain has lower levels of phosphocreatine in the beginning stages of the disease ${ }^{101,106}$. Although creatine kinase levels were reduced, studies have questioned the involvement of creatine upon finding deposits of the molecule in amyloid precursor protein (APP) in transgenic mice ${ }^{107}$. The solubility of creatine in an aqueous solution is $100 \mathrm{mM}$, however the total creatine concentration 
in the brain only reaches $20 \mathrm{mM}^{10}$. Possible explanations for the origin of these creatine deposits in the transgenic mice models include: (1) spillage from neuronal cell death, (2) excess oligodendrocyte production of creatine, (3) limited creatine uptake by the CRT and (4) the oxidation of creatine kinase that limits the formation of phosphocreatine ${ }^{108-111}$. Although each of these possibilities has been studied extensively, it remains unclear to the exact origin of the creatine deposits. This further reiterates that the exact role of creatine in AD is still yet to be understood and may be more complicated than previously thought.

\section{Stroke}

Stroke is "defined as an acute neurologic dysfunction of vascular origin with sudden (within seconds) or a least rapid (within hours) occurrence of symptoms and signs corresponding to the involvement of focal areas in the brain" 112 . In the past decade, stroke has been the second leading cause of death ${ }^{113}$. Ischemic stroke, which is more common ${ }^{114,115}$, occurs when the brain is deprived of glucose and oxygen due to insufficient blood supply. This causes acidosis, an increase in intracellular calcium, and the formation of reactive oxygen species leading to ischemic cell death ${ }^{116}$. Symptoms of ischemic stroke include sudden numbness on one side of the body, vision disturbances, difficulty in speaking and understanding, imbalance, and loss of coordination. The available treatments for ischemic stroke consist of the use of tissue plasminogen activator (tPA) $)^{117}$ and/or surgical treatments. The commonly used in vitro model for ischemic stroke involves oxygen-glucose deprivation ${ }^{118,119}$ and rodent model for stroke involves mechanical or thromboembolic occlusion of cerebral vessel to mimic cerebral ischemia ${ }^{120-123}$.

An early study involving eight stroke patients has demonstrated that creatine and phosphocreatine content is reduced in the ischemic brain $^{124}$. In rat hippocampal slices, pre-incubation with creatine (0.03-3 mmol/L) dose-dependently reduced damage due to anoxia ${ }^{125}$. Another in-vitro study in rat hippocampal slices showed dose dependent increase in phosphocreatine concentration and delay in anoxic depolarization after incubation with $1 \mathrm{mM}$ creatine ${ }^{126}$. Creatine was shown to exert protective antioxidant effect in U937 human promonocytic cells after oxidative damage ${ }^{127}$. Creatine has been shown to be neuroprotective in an experimental model of anoxia in neonatal mice supplemented with creatine ${ }^{128-130}$. Also, rats subjected to creatine pretreatment before cerebral hypoxia showed a reduction (25\%) in the volume of edematous brain tissue compared when compared to control ${ }^{131}$. Zhu et al. showed that mice supplemented with $2 \%$ creatine in the diet showed reduced neuronal damage compared to control groups following middle cerebral artery occlusion that causes ischemic stroke. The study indicated that this beneficial effect of creatine is due to the restoration of energy depletion and inhibition of caspase activation along with some other unknown mechanisms ${ }^{132}$. These studies support the fact that creatine could be a potential compound to be used as a prophylactic, or preventative, dietary supplement in patients at high risk for stroke ${ }^{133}$. Still, more work is needed to demonstrate the efficacy of creatine to prevent stroke and to develop a creatine supplementation regimen to help patients at risk for stroke to avoid the debilitating event.

\section{Conclusions}

Creatine has the potential to elicit positive effects in muscle strength, memory, and has further influence on neurodegenerative conditions. It remains to be seen if creatine has the ability to alter age-associated, progressive neurodegenerative disorders once individuals are in intermediate or late stages of the disease. However, based on the creatine interaction with energy metabolism and subsequent neuroprotective mechanisms, the interest for studying alternative uses for creatine in physiology is enhanced. Unfortunately, the phase III clinical trial for Parkinson's disease and creatine was halted. However, there are ongoing clinical trials for creatine. Creatine supplementation is in a phase III clinical trial for the treatment of the energetic deficiencies in Huntington's disease. With promising effects thus far, CREST-E remains continually funded by the National Center for Complementary and Alternative Medicine (NCCAM) and the Food and Drug Administration (FDA) as the largest therapeutic trial ever for Huntington's disease. The usefulness of this compound may prove an important deterrent at beginning stages of dementia or even for increasing muscle strength in Parkinson's disease patients. Furthermore, creatine may serve as a preventative treatment for the long-term consequences of stroke but may play a more complicated role in Alzheimer's disease. Despite the wide range of uses for creatine supplementation, this dietary supplement should be the focus of additional studies for the treatment of age-related diseases. Going forward, one must consider if there are other mechanisms for which creatine acts to be protective and beneficial. These alternative mechanisms and the molecular/cellular targets for creatine remain to be determined and fully characterized.

\section{Author contributions}

RNS wrote the first draft of the manuscript, performed the initial literature search, and revised the manuscript. ASA contributed to the literature search, wrote sections of the manuscript, revised the manuscript, and formatted the references. EBG provided overall supervision, along with critical review and revision of the final manuscript. All authors have read and agreed to the publication of the article.

\section{Competing interests}

No competing interests were disclosed.

\section{Grant information}

Rachel N. Smith is supported by a fellowship on an NIH National Institute on Aging Training Grant (T32AG020494). Eric B. Gonzales is supported by an American Heart Association Beginning Grant-in-Aid (12BGIA8820001) and an UNTHSC Institute for Aging and Alzheimer's Disease Research (IAADR) Pilot Seed Grant.

The funders had no role in study design, data collection and analysis, decision to publish, or preparation of the manuscript.

\section{Acknowledgements}

The authors would like to thank members of the Gonzales laboratory for their helpful discussions. 
1. Zeisel SH: Regulation of "nutraceuticals". Science. 1999; 285(5435): 1853-1855. PubMed Abstract | Publisher Full Text

2. Schnirring L: Creatine supplements face scrutiny: Will users pay later? Phys Sports Med. 1998; 26: 15-23.

3. Bloch K, Schoenheimer R: The Biological Precursors Of Creatine. J Biol Chem. 1941; 138(1): 167-194.

Reference Source

4. Tarnopolsky MA, Beal MF: Potential for creatine and other therapies targeting cellular energy dysfunction in neurological disorders. Ann Neurol. 2001; 49(5): $561-574$

PubMed Abstract | Publisher Full Text

5. Adhihetty PJ, Beal MF: Creatine and its potential therapeutic value for targeting cellular energy impairment in neurodegenerative diseases. Neuromolecular Med. 2008; 10(4): 275-290.

PubMed Abstract | Publisher Full Text | Free Full Text

6. Christie DL: Functional insights into the creatine transporter. In: Gajja S. Salomons, M Wyss, ed. Creatine and creatine kinase in health and disease. Netherlands: Springer; 2007; 46: 99-118. Publisher Full Text

7. Lowe MT, Faull RL, Christie DL, et al.: The distribution of the creatine transporter throughout the human brain reveals a spectrum of creatine transporter immunoreactivity. J Comp Neurol. 2014. PubMed Abstract | Publisher Full Text

8. Walker JB: Creatine: biosynthesis, regulation, and function. Adv Enzymol Relat Areas Mol Biol. 1979; 50: 177-242.

PubMed Abstract | Publisher Full Text

9. Adhihetty PJ, Irrcher I, Joseph AM, et al:: Plasticity of skeletal muscle mitochondria in response to contractile activity. Exp Physiol. 2003; 88(1): 99-107. PubMed Abstract | Publisher Full Text

10. Wallimann T, Wyss M, Brdiczka D, et al.: Intracellular compartmentation, structure and function of creatine kinase isoenzymes in tissues with high and fluctuating energy demands: the 'phosphocreatine circuit' for cellular energy homeostasis. Biochem J. 1992; 281(Pt 1): 21-40. PubMed Abstract | Free Full Text

11. Peng TI, Greenamyre JT: Privileged access to mitochondria of calcium influx through N-methyl-D-aspartate receptors. Mol Pharmacol. 1998; 53(6): 974-980. PubMed Abstract

12. Green DR, Reed JC: Mitochondria and apoptosis. Science. 1998; 281(5381): 1309-1312. PubMed Abstract | Publisher Full Text

13. Steeghs $\mathrm{K}$, Benders $\mathrm{A}$, Oerlemans $\mathrm{F}$, et al.: Altered $\mathrm{Ca} 2+$ responses in muscles with combined mitochondrial and cytosolic creatine kinase deficiencies. Cell. 1997; 89(1): 93-103. PubMed Abstract | Publisher Full Text

14. Wyss $\mathrm{M}$, Braissant $\mathrm{O}$, Pischel I, et al.: Creatine and creatine kinase in health and disease--a bright future ahead? Subcell Biochem. 2007; 46: 309-334. PubMed Abstract | Publisher Full Text

15. Xu CJ, Klunk WE, Kanfer JN, et al.: Phosphocreatine-dependent glutamate uptake by synaptic vesicles. A comparison with atp-dependent glutamate uptake. J Biol Chem. 1996; 271(23): 13435-13440.

PubMed Abstract | Publisher Full Text

16. Lawler JM, Barnes WS, Wu G, et al.: Direct antioxidant properties of creatine. Biochem Biophys Res Commun. 2002; 290(1): 47-52.

PubMed Abstract | Publisher Full Text

17. Dedeoglu A, Kubilus JK, Yang L, et al.: Creatine therapy provides neuroprotection after onset of clinical symptoms in Huntington's disease transgenic mice. J Neurochem. 2003; 85(6): 1359-1367. PubMed Abstract | Publisher Full Text | Free Full Text

18. Araujo MB, Moura LP, Junior RC, et al:: Creatine supplementation and oxidative stress in rat liver. $J$ Int Soc Sports Nutr. 2013; 10(1): 54 PubMed Abstract | Publisher Full Text | Free Full Text

19. de Andrade RB, Gemelli T, Rojas DB, et al:: Creatine and Pyruvate Preven the Alterations Caused by Tyrosine on Parameters of Oxidative Stress and Enzyme Activities of Phosphoryltransfer Network in Cerebral Cortex of Wistar Rats. Mol Neurobiol. 2014.

PubMed Abstract | Publisher Full Text

20. Stefani GP, Nunes RB, Dornelles AZ et al: Effects of creatine supplementation associated with resistance training on oxidative stress in different tissues of rats. J Int Soc Sports Nutr. 2014; 11(1): 11.

PubMed Abstract | Publisher Full Text | Free Full Text

21. Chevreul ME: Sur une nouvelle substance contenue dans la chair de boeuf. Paris Mus Hist Nat N Ann. 1832; I: 306-316.

22. Wyss M, Kaddurah-Daouk R: Creatine and creatinine metabolism. Physiol Rev 2000; 80(3): 1107-1213

PubMed Abstract

23. Harris RC, Soderlund K, Hultman E: Elevation of creatine in resting and exercised muscle of normal subjects by creatine supplementation. Clin Sci (Lond). 1992 83(3): 367-374.

PubMed Abstract
24. Green AL, Simpson EJ, Littlewood JJ, et al:: Carbohydrate ingestion augments creatine retention during creatine feeding in humans. Acta Physiol Scand. 1996; 158(2): 195-202.

PubMed Abstract | Publisher Full Text

25. Steenge GR, Simpson EJ, Greenhaff PL: Protein- and carbohydrate-induced augmentation of whole body creatine retention in humans. J Appl Physiol (1985). 2000; 89(3): 1165-1171. PubMed Abstract

26. Burke DG, Chilibeck Pd, Parise GA, et al.: The effect of alpha lipoic acid supplementation on resting muscle creatine during acute creatine loading FASEB J. 2001; 15(5): A814.

27. Greenwood M, Kreider RB, Almada AL, et al.: D-pinitol augments whole body creatine retention in man. J Exercise Physiol Online. 2001; 4(4): 41-47. Reference Sourc

28. Persky AM, Brazeau GA: Clinical pharmacology of the dietary supplement creatine monohydrate. Pharmacol Rev. 2001; 53(2): 161-176. PubMed Abstract

29. Izquierdo M, Ibanez J, Gonzalez-Badillo JJ, et al:: Effects of creatine supplementation on muscle power, endurance, and sprint performance. Med Sci Sports Exerc. 2002; 34(2): 332-343 PubMed Abstract

30. Mujika I, Padilla S, Ibanez J, et al.: Creatine supplementation and sprint performance in soccer players. Med Sci Sports Exerc. 2000; 32(2): 518-525. PubMed Abstract | Publisher Full Text

31. Becque MD, Lochmann JD, Melrose DR: Effects of oral creatine supplementation on muscular strength and body composition. Med Sci Sports Exerc. 2000; 32(3): 654-658.

PubMed Abstract | Publisher Full Text

32. Kreider RB, Ferreira M, Wilson M, et al.: Effects of creatine supplementation on body composition, strength, and sprint performance. Med Sci Sports Exerc. 1998; 30(1): 73-82. PubMed Abstract | Publisher Full Text

33. Vandenberghe $\mathrm{K}$, Goris $\mathrm{M}$, Van Hecke P, et al.: Long-term creatine intake is beneficial to muscle performance during resistance training. J Appl Physio (1985). 1997; 83(6): 2055-2063. PubMed Abstract

34. Volek JS, Boetes M, Bush JA, et al.: Response of testosterone and cortisol concentrations to high-intensity resistance exercise following creatine supplementation. J Strength Conditioning Res. 1997; 11(3). Reference Source

35. Jacobs I, Bleue S, Goodman J: Creatine ingestion increases anaerobic capacity and maximum accumulated oxygen deficit. Can J Appl Physiol. 1997; 22(3): $231-243$.

PubMed Abstract | Publisher Full Text

36. Dawson B, Cutler M, Moody A, et al:: Effects of oral creatine loading on single and repeated maximal short sprints. Aust J Sci Med Sport. 1995; 27(3): 56-61. PubMed Abstract

37. Meir R: Practical application of oral creatine supplementation in professional rugby league: A case study. Australian Strength and Conditioning Coach. 1995; 3(3): 6-10.

Reference Source

38. Antonio J, Ciccone V: The effects of pre versus post workout supplementation of creatine monohydrate on body composition and strength. $J$ Int Soc Sports Nutr. 2013; 10: 36

PubMed Abstract | Publisher Full Text | Free Full Text

39. de Salles Painelli V, Alves VT, Ugrinowitsch C, et al.: Creatine supplementation prevents acute strength loss induced by concurrent exercise. Eur J Appl Physiol. 2014; 114(8): 1749-1755.

PubMed Abstract | Publisher Full Text

40. Camic CL, Housh TJ, Zuniga JM, et al:: The effects of polyethylene glycosylated creatine supplementation on anaerobic performance measures and body composition. J Strength Cond Res. 2014; 28(3): 825-833. PubMed Abstract | Publisher Full Text

41. Mesa JL, Ruiz JR, Gonzalez-Gross MM, et al.: Oral creatine supplementation and skeletal muscle metabolism in physical exercise. Sports Med. 2002; 32(14): 903-944

PubMed Abstract | Publisher Full Text

42. Persky AM, Muller M, Derendorf $\mathrm{H}$, et al.: Single- and multiple-dose pharmacokinetics of oral creatine. J Clin Pharmacol. 2003; 43(1): 29-37. PubMed Abstract | Publisher Full Text

43. Hall M, Trojian TH: Creatine supplementation. Curr Sports Med Rep. 2013; 12(4) 240-244. PubMed Abstract | Publisher Full Text

44. Anderson O: Creatine propels british athletes to olympic gold medals: Is creatine the one true ergogenic aid? Running Research News. 1993; 9: 1-5.

45. Greenhaff PL, Casey A, Short AH, et al.: Influence of oral creatine supplementation of muscle torque during repeated bouts of maximal voluntary exercise in man. Clin Sci (Lond). 1993; 84(5): 565-571. PubMed Abstract 
46. Wyss M, Schulze A: Health implications of creatine: can oral creatine supplementation protect against neurological and atherosclerotic disease? Neuroscience. 2002; 112(2): 243-260.

PubMed Abstract | Publisher Full Text

47. Genc G, Okuyucu A, Meydan BC, et al.: Effect of free creatine therapy on cisplatin-induced renal damage. Ren Fail. 2014; 36(7): 1108-1113. PubMed Abstract | Publisher Full Text

48. Dickinson $\mathrm{H}$, Ellery S, Ireland $\mathrm{Z}$, et al:: Creatine supplementation during pregnancy: summary of experimental studies suggesting a treatment to improve fetal and neonatal morbidity and reduce mortality in high-risk human pregnancy. BMC Pregnancy Childbirth. 2014; 14: 150.

PubMed Abstract | Publisher Full Text | Free Full Text

49. Leader A, Amital D, Rubinow A, et al:: An open-label study adding creatine monohydrate to ongoing medical regimens in patients with the fibromyalgia syndrome. Ann N Y Acad Sci. 2009; 1173: 829-836. PubMed Abstract | Publisher Full Text

50. Kreider RB: Effects of creatine supplementation on performance and training adaptations. Mol Cell Biochem. 2003; 244(1-2): 89-94. PubMed Abstract | Publisher Full Text

51. Candow DG, Chilibeck PD, Forbes SC: Creatine supplementation and aging musculoskeletal health. Endocrine. 2014; 45(3): 354-361. PubMed Abstract | Publisher Full Text

52. Lang AE, Lozano AM: Parkinson's disease. First of two parts. N Engl J Med. 1998; 339(15): 1044-1053.

PubMed Abstract | Publisher Full Text

53. Beal MF: Mitochondria, free radicals, and neurodegeneration. Curr Opin Neurobiol. 1996; 6(5): 661-666.

PubMed Abstract | Publisher Full Text

54. Thomas B, Beal MF: Parkinson's disease. Hum Mol Genet. 2007; 16(R2): R183-94 Publisher Full Text

55. Matthews RT, Ferrante RJ, Klivenyi P, et al:: Creatine and cyclocreatine attenuate MPTP neurotoxicity. Exp Neurol. 1999; 157(1): 142-149.

PubMed Abstract | Publisher Full Text

56. NINDS NET-PD Investigators. A randomized, double-blind, futility clinical trial of creatine and minocycline in early Parkinson disease. Neurology. 2006; 66(5) 664-671.

PubMed Abstract | Publisher Full Text

57. Hass CJ, Collins MA, Juncos JL: Resistance training with creatine monohydrate improves upper-body strength in patients with Parkinson disease: a randomized trial. Neurorehabil Neural Repair. 2007; 21(2): 107-115. PubMed Abstract | Publisher Full Text

58. Statement on the termination of NET-PD LS-1 study. NET-PD NIH Exploratory Trials in Parkinson's Disease Web site. 2013. Reference Source

59. Walker FO: Huntington's disease. Lancet. 2007; 369(9557): 218-228. PubMed Abstract | Publisher Full Text

60. Strong TV, Tagle DA, Valdes JM, et al:: Widespread expression of the human and rat Huntington's disease gene in brain and nonneural tissues. Nat Genet. 1993. 5(3): 259-265

PubMed Abstract | Publisher Full Tex

61. Landwehrmeyer GB, McNeil SM, Dure LS 4th, et al:: Huntington's disease gene: regional and cellular expression in brain of normal and affected individuals. Ann Neurol. 1995; 37(2): 218-230. PubMed Abstract | Publisher Full Text

62. Sharp AH, Loev SJ, Schilling G, et al:: Widespread expression of Huntington's disease gene (IT15) protein product. Neuron. 1995; 14(5): 1065-1074. PubMed Abstract | Publisher Full Text

63. Ferrante RJ, Gutekunst CA, Persichetti F, et al:: Heterogeneous topographic and cellular distribution of huntingtin expression in the normal human neostriatum. J Neurosci. 1997; 17(9): 3052-3063. PubMed Abstract

64. Ryu H, Ferrante RJ: Emerging chemotherapeutic strategies for Huntington's disease. Expert Opin Emerg Drugs. 2005; 10(2): 345-363. PubMed Abstract | Publisher Full Tex

65. Koroshetz WJ, Jenkins BG, Rosen BR, et al:: Energy metabolism defects in Huntington's disease and effects of coenzyme Q10. Ann Neurol. 1997; 41(2): 160-165.

PubMed Abstract | Publisher Full Text

66. Wallimann T, Hemmer W: Creatine kinase in non-muscle tissues and cells. $\mathrm{MO}$ Cell Biochem. 1994; 133-134: 193-220. PubMed Abstract | Publisher Full Tex

67. O'Gorman $\mathrm{E}$, Beutner $\mathrm{G}$, Dolder $\mathrm{M}$, et al: The role of creatine kinase in inhibition of mitochondrial permeability transition. FEBS Lett. 1997; 414(2): 253-257. PubMed Abstract | Publisher Full Text

68. Matthews RT, Yang L, Jenkins BG, et al.: Neuroprotective effects of creatine and cyclocreatine in animal models of Huntington's disease. J Neurosci. 1998; 18(1): 156-163. PubMed Abstract

69. Ferrante RJ, Andreassen OA, Jenkins BG, et al:: Neuroprotective effects of creatine in a transgenic mouse model of Huntington's disease. $J$ Neurosci. 2000; 20(12): 4389-4397.

PubMed Abstract

70. Brouillet E, Jenkins BG, Hyman BT, et al.: Age-dependent vulnerability of the striatum to the mitochondrial toxin 3-nitropropionic acid. J Neurochem. 1993; 60(1): 356-359

PubMed Abstract | Publisher Full Tex

71. Beal MF, Brouillet E, Jenkins BG, et al.: Neurochemical and histologic characterization of striatal excitotoxic lesions produced by the mitochondria toxin 3-nitropropionic acid. J Neurosci. 1993; 13(10): 4181-4192. PubMed Abstract

72. Schulz JB, Beal MF: Neuroprotective effects of free radical scavengers and energy repletion in animal models of neurodegenerative disease. Ann NY Acad Sci. 1995; 765: 100-10; discussion 116-8. PubMed Abstract | Publisher Full Text

73. Browne SE, Ferrante RJ, Beal MF: Oxidative stress in Huntington's disease. Brain Pathol. 1999; 9(1): 147-163. PubMed Abstract | Publisher Full Text

74. Grunewald T, Beal MF: Bioenergetics in Huntington's disease. Ann NY Acad Sci. 1999; 893: 203-213.

PubMed Abstract | Publisher Full Text

75. Andreassen OA, Dedeoglu A, Ferrante RJ, et al:: Creatine increase survival and delays motor symptoms in a transgenic animal model of Huntington's disease. Neurobiol Dis. 2001; 8(3): 479-491.

PubMed Abstract | Publisher Full Text

76. Hersch SM, Gevorkian S, Marder K, et al.: Creatine in huntington disease is safe, tolerable, bioavailable in brain and reduces serum $\mathbf{8 0 H 2 ' d G . ~ N e u r o l o g y . ~ 2 0 0 6 ; ~}$ 66(2): 250-252.

PubMed Abstract | Publisher Full Text

77. Kim J, Amante DJ, Moody JP, et al:: Reduced creatine kinase as a central and peripheral biomarker in Huntington's disease. Biochim Biophys Acta. 2010; 1802(7-8): 673-681.

PubMed Abstract | Publisher Full Text | Free Full Text

78. Walton JN: Brain's diseases of the nervous system. 10th ed. New York: Oxford University Press, 1993: 443-449.

Reference Source

79. Dementia and motoneurone disease. Lancet. 1990; 335(8700): 1250-1252. Publisher Full Text

80. Hervias I, Beal MF, Manfredi G: Mitochondrial dysfunction and amyotrophic lateral sclerosis. Muscle Nerve. 2006; 33(5): 598-608. PubMed Abstract | Publisher Full Text

81. Dugdale DC, Hoch DB, Zieve D: Amyotrophic lateral sclerosis. A D A M Medical Encyclopedia. 2010.

82. Zoccolella S, Beghi E, Palagano G, et al:: Riluzole and amyotrophic lateral sclerosis survival: a population-based study in southern italy. Eur J Neurol. 2007; 14(3): 262-268.

PubMed Abstract | Publisher Full Text

83. Phukan J, Pender NP, Hardiman O: Cognitive impairment in amyotrophic lateral sclerosis. Lancet Neurol. 2007; 6(11): 994-1003. PubMed Abstract | Publisher Full Text

84. Strong M, Rosenfeld J: Amyotrophic lateral sclerosis: a review of current concepts. Amyotroph Lateral Scler Other Motor Neuron Disord. 2003; 4(3): 136-143. PubMed Abstract | Publisher Full Text

85. Siklos L, Engelhardt J, Harati Y, et al:: Ultrastructural evidence for altered calcium in motor nerve terminals in amyotropic lateral sclerosis. Ann Neurol. 1996; 39(2): 203-216.

PubMed Abstract | Publisher Full Text

86. Carri MT, Ferri A, Battistoni A, et al:: Expression of a $\mathrm{Cu}, \mathrm{Zn}$ superoxide dismutase typical of familial amyotrophic lateral sclerosis induces mitochondrial alteration and increase of cytosolic $\mathrm{Ca} 2+$ concentration in transfected neuroblastoma SH-SY5Y cells. FEBS Lett. 1997; 414(2): 365-368. PubMled Abstract | Publisher Full Text

87. Kasarskis EJ, Berryman S, Vanderleest JG, et al: Nutritional status of patients with amyotrophic lateral sclerosis: relation to the proximity of death. Am J Clin Nutr. 1996; 63(1): 130-137. PubMed Abstract

88. Reaume AG, Elliott JL, Hoffman EK, et al:: Motor neurons in Cu/Zn superoxide dismutase-deficient mice develop normally but exhibit enhanced cell death after axonal injury. Nat Genet. 1996; 13(1): 43-47. PubMed Abstract | Publisher Full Text

89. Bruijn LI, Houseweart MK, Kato S, et al:: Aggregation and motor neuron toxicity of an ALS-linked SOD1 mutant independent from wild-type SOD1. Science. 1998; 281(5384): 1851-1854. PubMed Abstract | Publisher Full Text

90. Klivenyi P, Ferrante RJ, Matthews RT, et al:: Neuroprotective effects of creatine in a transgenic animal model of amyotrophic lateral sclerosis. Nat Med. 1999; 5(3): 347-350.

PubMed Abstract | Publisher Full Text

91. Shefner JM, Cudkowicz ME, Schoenfeld D, et al.: A clinical trial of creatine in ALS. Neurology. 2004; 63(9): 1656-1661. PubMed Abstract | Publisher Full Text

92. Groeneveld GJ, Veldink JH, van der Tweel I, et al:: A randomized sequential trial of creatine in amyotrophic lateral sclerosis. Ann Neurol. 2003; 53(4): 437-445. PubMed Abstract | Publisher Full Text

93. Hedden T, Gabrieli JD: Insights into the ageing mind: a view from cognitive neuroscience. Nat Rev Neurosci. 2004; 5(2): 87-96. PubMled Abstract | Publisher Full Text 
94. Nilsson LG: Memory function in normal aging. Acta Neurol Scand Suppl. 2003 179: 7-13

PubMed Abstract

95. Sappey-Marinier D, Calabrese G, Fein G, et al:: Effect of photic stimulation on human visual cortex lactate and phosphates using $1 \mathrm{H}$ and $31 \mathrm{P}$ magnetic resonance spectroscopy. J Cereb Blood Flow Metab. 1992; 12(4): 584-592. PubMed Abstract | Publisher Full Text

96. Rango M, Castelli A, Scarlato G: Energetics of 3.5 s neural activation in humans: a 31P MR spectroscopy study. Magn Reson Med. 1997; 38(6): 878-883. PubMed Abstract

97. Rae C, Digney AL, McEwan SR, et al.: Oral creatine monohydrate supplementation improves brain performance: a double-blind, placebocontrolled, cross-over trial. Proc Biol Sci. 2003; 270(1529): 2147-2150. PubMed Abstract | Publisher Full Text | Free Full Text

98. Lyoo IK, Kong SW, Sung SM, et al:: Multinuclear magnetic resonance spectroscopy of high-energy phosphate metabolites in human brain following oral supplementation of creatine-monohydrate. Psychiatry Res. 2003; 123(2): $87-100$.

PubMed Abstract | Publisher Full Text

99. McMorris T, Mielcarz G, Harris RC, et al.: Creatine supplementation and cognitive performance in elderly individuals. Neuropsychol Dev Cogn B Aging Neuropsychol Cogn. 2007; 14(5): 517-528. PubMed Abstract | Publisher Full Text

100. Tiraboschi P, Hansen LA, Thal LJ, et al.: The importance of neuritic plaques and tangles to the development and evolution of AD. Neurology. 2004; 62(11): 1984-1989.

PubMed Abstract | Publisher Full Text

101. Pettegrew JW, Panchalingam K, Klunk WE, et al:: Alterations of cerebral metabolism in probable Alzheimer's disease: a preliminary study. Neurobiol Aging. 1994; 15(1): 117-132. PubMed Abstract | Publisher Full Tex

102. Shonk T, Ross BD: Role of increased cerebral myo-inositol in the dementia of Down syndrome. Magn Reson Med. 1995; 33(6): 858-861. PubMed Abstract

103. Huang W, Alexander GE, Daly EM, et al:: High brain myo-inositol levels in the predementia phase of Alzheimer's disease in adults with Down's syndrome: a 1H MRS study. Am J Psychiatry. 1999; 156(12): 1879-1886. PubMed Abstract

104. Brewer GJ, Wallimann TW: Protective effect of the energy precursor creatine against toxicity of glutamate and beta-amyloid in rat hippocampal neurons. J Neurochem. 2000; 74(5): 1968-1978. PubMed Abstract | Publisher Full Text

105. Castegna A, Aksenov M, Thongboonkerd V, et al:: Proteomic identification of oxidatively modified proteins in Alzheimer's disease brain. Part II: dihydropyrimidinase-related protein 2 , alpha-enolase and heat shock cognate 71. J Neurochem. 2002; 82(6): 1524-1532. PubMed Abstract | Publisher Full Text

106. David S, Shoemaker M, Haley BE: Abnormal properties of creatine kinase in Alzheimer's disease brain: correlation of reduced enzyme activity and active site photolabeling with aberrant cytosol-membrane partitioning. Brain Res $\mathrm{Mo}$ Brain Res. 1998; 54(2): 276-287. PubMed Abstract | Publisher Full Text

107. Gallant M, Rak M, Szeghalmi A, et al.: Focally elevated creatine detected in amyloid precursor protein (APP) transgenic mice and Alzheimer disease brain tissue. J Biol Chem. 2006; 281(1): 5-8. PubMed Abstract | Publisher Full Text

108. Tachikawa M, Fukaya M, Terasaki T, et al.: Distinct cellular expressions of creatine synthetic enzyme GAMT and creatine kinases uCK-Mi and CK-B suggest a novel neuron-glial relationship for brain energy homeostasis. Eur J Neurosci. 2004; 20(1): 144-160. PubMed Abstract | Publisher Full Text

109. Braissant $\mathrm{O}$, Henry $\mathrm{H}$, Villard $\mathrm{AM}$, et al.: Creatine synthesis and transport during rat embryogenesis: spatiotemporal expression of AGAT, GAMT and CT1. BMC Dev Biol. 2005; 5: 9

PubMed Abstract | Publisher Full Text | Free Full Text

110. Straumann $\mathrm{N}$, Wind $\mathrm{A}$, Leuenberger $\mathrm{T}$, et al.: Effects of $\mathrm{N}$-linked glycosylation on the creatine transporter. Biochem J. 2006; 393(Pt 2): 459-469. PubMed Abstract | Publisher Full Text | Free Full Text

111. Stachowiak $\mathrm{O}$, Dolder $\mathrm{M}$, Wallimann $\mathrm{T}$, et al:: Mitochondrial creatine kinase is a prime target of peroxynitrite-induced modification and inactivation. $J$ Biol Chem. 1998; 273(27): 16694-16699. PubMed Abstract | Publisher Full Text

112. Stroke--1989. recommendations on stroke prevention, diagnosis, and therapy report of the WHO task force on stroke and other cerebrovascular disorders. Stroke. 1989; 20(10): 1407-1431. PubMed Abstract | Publisher Full Text
113. World health organization: the top 10 causes of death. 2014 Reference Source

114. Hickey JV: The clinical practice of neurological and neurosurgical nursing. 5th ed. Philadelphia: Lippincott, Williams \& Wilkins, 2003. Reference Source

115. Ingall T: Stroke--incidence, mortality, morbidity and risk. J Insur Med. 2004; 36(2): 143-152. PubMed Abstract

116. Warner DS, Sheng $\mathrm{H}$, Batinic-Haberle I: Oxidants, antioxidants and the ischemic brain. J Exp Biol. 2004; 207(Pt 18): 3221-3231. PubMed Abstract | Publisher Full Text

117. Wardlaw JM, Murray V, Berge $\mathrm{E}$, et al.: Thrombolysis for acute ischaemic stroke. Cochrane Database Syst Rev. 2009; (4): CD000213. PubMed Abstract | Publisher Full Text

118. Richard MJ, Saleh TM, El Bahh B, et al:: A novel method for inducing focal ischemia in vitro. $J$ Neurosci Methods. 2010; 190(1): 20-27. PubMed Abstract | Publisher Full Text

119. Ye R, Li N, Han J, et al:: Neuroprotective effects of ginsenoside Rd against oxygen-glucose deprivation in cultured hippocampal neurons. Neurosci Res. 2009; 64(3): 306-310 PubMed Abstract | Publisher Full Text

120. Menzies SA, Hoff JT, Betz AL: Middle cerebral artery occlusion in rats: a neurological and pathological evaluation of a reproducible model. Neurosurgery. 1992; 31(1): 100-6; discussion 106-7. PubMed Abstract

121. Miyake K, Takeo S, Kaijihara H: Sustained decrease in brain regional blood flow after microsphere embolism in rats. Stroke. 1993; 24(3): 415-420. PubMed Abstract | Publisher Full Text

122. Bacigaluppi M, Comi G, Hermann DM: Animal models of ischemic stroke. Part two: modeling cerebral ischemia. Open Neurol J. 2010; 4: 34-38. PubMed Abstract | Publisher Full Text | Free Full Text

123. Arsava EM, Gurer G, Gursoy-Ozdemir Y, et al:: A new model of transient focal cerebral ischemia for inducing selective neuronal necrosis. Brain Res Bull. 2009; 78(4-5): 226-231. PubMed Abstract | Publisher Full Text

124. Gideon P, Henriksen O, Sperling B, et al.: Early time course of $\mathrm{N}$-acetylaspartate, creatine and phosphocreatine, and compounds containing choline in the brain after acute stroke. A proton magnetic resonance spectroscopy study. Stroke. 1992; 23(11): 1566-1572. PubMed Abstract | Publisher Full Text

125. Carter AJ, Muller RE, Pschorn U, et al:: Preincubation with creatine enhances levels of creatine phosphate and prevents anoxic damage in rat hippocampal slices. J Neurochem. 1995; 64(6): 2691-2699. PubMed Abstract | Publisher Full Text

126. Balestrino M, Rebaudo R, Lunardi G: Exogenous creatine delays anoxic depolarization and protects from hypoxic damage: dose-effect relationship. Brain Res. 1999; 816(1): 124-130. PubMed Abstract | Publisher Full Text

127. Sestili $P$, Martinelli C, Bravi G, et al:: Creatine supplementation affords cytoprotection in oxidatively injured cultured mammalian cells via direct antioxidant activity. Free Radic Biol Med. 2006; 40(5): 837-849. PubMed Abstract | Publisher Full Text

128. Wilken B, Ramirez JM, Probst I, et al:: Anoxic ATP depletion in neonatal mice brainstem is prevented by creatine supplementation. Arch Dis Child Fetal Neonatal Ed. 2000; 82(3): F224-7.

PubMed Abstract | Publisher Full Text | Free Full Text

129. Otellin VA, Korzhevskii DE, Kostkin VB, et al.: The neuroprotective effect of creatine in rats with cerebral ischemia. Dokl Biol Sci. 2003; 390: 197-199. PubMed Abstract | Publisher Full Text

130. Lensman M, Korzhevskii DE, Mourovets VO, et al.: Intracerebroventricular administration of creatine protects against damage by global cerebral ischemia in rat. Brain Res. 2006; 1114(1): 187-194. PubMed Abstract | Publisher Full Text

131. Adcock KH, Nedelcu J, Loenneker T, et al:: Neuroprotection of creatine supplementation in neonatal rats with transient cerebral hypoxia-ischemia. Dev Neurosci. 2002; 24(5): 382-388. PubMed Abstract | Publisher Full Tex

132. Zhu S, Li M, Figueroa BE, et al:: Prophylactic creatine administration mediates neuroprotection in cerebral ischemia in mice. J Neurosci. 2004; 24(26): 5909-5912. PubMed Abstract | Publisher Full Text

133. Perasso L, Spallarossa $P$, Gandolfo $C$, et al:: Therapeutic use of creatine in brain or heart ischemia: available data and future perspectives. Med Res Rev. 2013 33(2): 336-363.

PubMed Abstract | Publisher Full Text 


\section{Open Peer Review}

\section{Current Peer Review Status:}

\section{Version 1}

Reviewer Report 16 January 2015

https://doi.org/10.5256/f1000research.5564.r7059

(C) 2015 Bickford P. This is an open access peer review report distributed under the terms of the Creative Commons Attribution License, which permits unrestricted use, distribution, and reproduction in any medium, provided the original work is properly cited.

\section{Paula Bickford}

Department of Neurosurgery and Brain Repair, University of South Florida College of Medicine, Tampa, FL, USA

This is an excellent review of the literature on creatine. I think that it would benefit from more discussion on possible side effects or toxicology. There are a number of review articles that discuss both the benefits and potential toxicology that could be included.

Overall the article is well written and a comprehensive review of the literature. It is interesting that such diverse effects are being seen in a wide range of degenerative diseases.

Competing Interests: No competing interests were disclosed.

I confirm that I have read this submission and believe that I have an appropriate level of expertise to confirm that it is of an acceptable scientific standard.

Reviewer Report 04 November 2014

\section{https://doi.org/10.5256/f1000research.5564.r6140}

(C) 2014 Simpkins J. This is an open access peer review report distributed under the terms of the Creative Commons Attribution License, which permits unrestricted use, distribution, and reproduction in any medium, provided the original work is properly cited.

\section{James Simpkins}

Department of Gastroenterology and Hepatology, West Virginia University Health Science Center, Baltimore, MD, 21205, USA

This is solid contribution to the literature on creatine and its possible beneficial role in acute and chronic neurodegenerative conditions. 
I have one major comment and several minor issues:

Major: the manuscript does not, but should, deal to any extent with possible side-effects of creatine supplementation. Particularly since the population proposed for intervention are largely elderly and very ill. A paragraph stating this and possible side-effects should suffice.

Minor things:

1. 'Parkinson's disease' section, paragraph 2, sentence 7, please insert "not" before "results".

2. 'Amyotrophic lateral sclerosis' section, second paragraph, SOD-1 is cytosolic, so more than just mitochondrial proteins would be affected. This paragraph should be changed to reflect this.

3. 'Long-term memory' section, third sentence, I would replace the term "dramatic" with another term as little drama happens in results of studies.

4. 'Alzheimer's disease' section, first sentence - the phrase should read "amyloid-containing plaques and neurofibrillary tangles".

5. 'Alzheimer's disease' section - define CRT.

Competing Interests: No competing interests were disclosed.

I confirm that I have read this submission and believe that I have an appropriate level of expertise to confirm that it is of an acceptable scientific standard.

The benefits of publishing with F1000Research:

- Your article is published within days, with no editorial bias

- You can publish traditional articles, null/negative results, case reports, data notes and more

- The peer review process is transparent and collaborative

- Your article is indexed in PubMed after passing peer review

- Dedicated customer support at every stage

For pre-submission enquiries, contact research@f1000.com 